СТАСЮК О.І., д.т.н., професор, ГОНЧАРОВА Л.Л., к.Т.Н., доценТ (ДЕТУТ), МАКСИМЧУК В.Ф., начальник Головного управління електрифікації та електропостачання Укрзалізниці

\title{
Методи синтезу розподілених комп'ютерно-інтегрованих мереж i технологій інтелектуалізації, моніторингу та оптимізації режимів електропостачання і енергозбереження залізниць
}

Розглянуті питання синтезу розподілених комп'ютерних мереж для проведення ковзкого безперервного моніторингу швидкоплинних технологічних процесів постачання електроенергї на тягу залізничному транспорту, організації єдиного простору первинної інформації для проведення оптимізації електроспоживання, мінімізації втрат, організації енергозберігаючих технологій і покращення рівня безпеки руху потягів.

Ключові слова: комп'ютерні мережі, моніторинг, первинна інформація, оптимізація, процес.

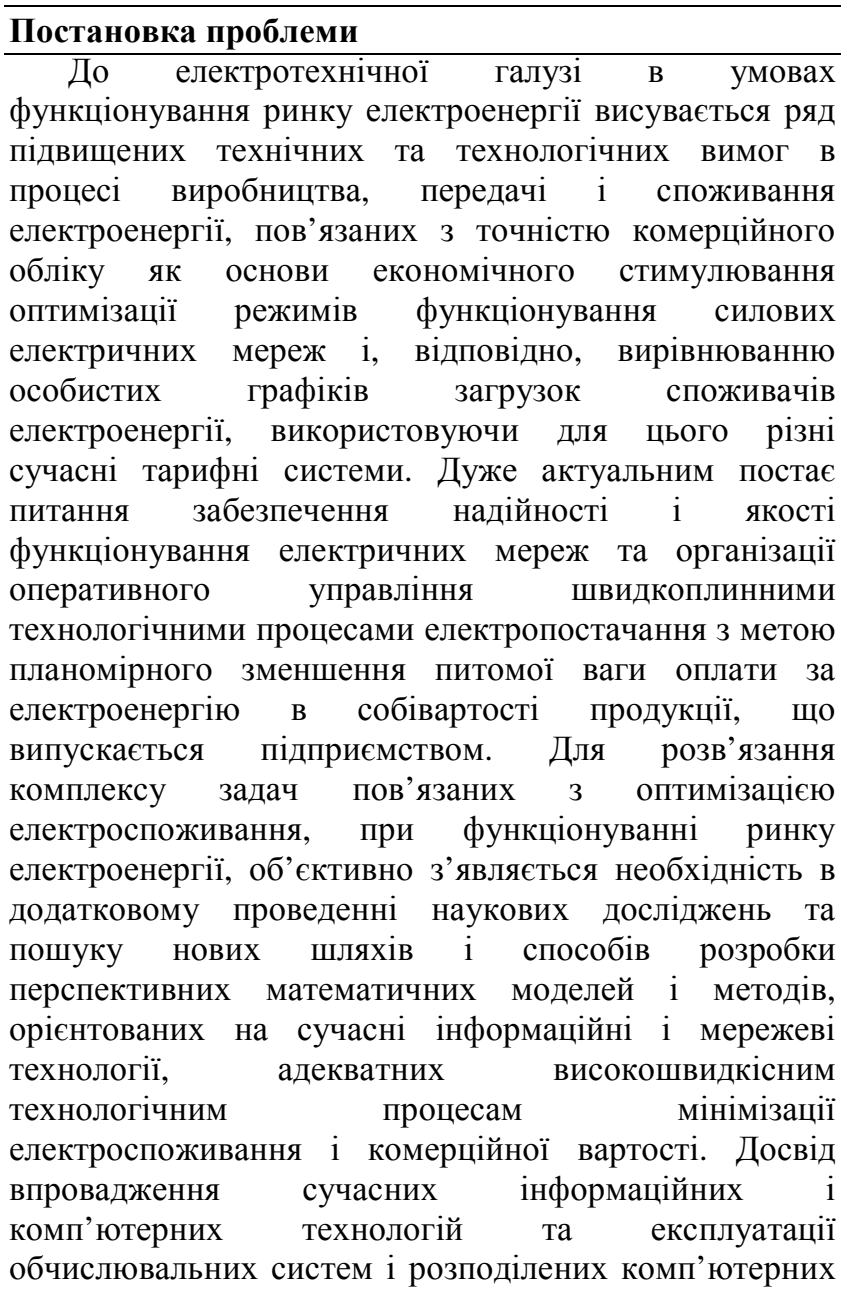

ㄷ О.І. Стасюк, Л.Л. Гончарова, В.Ф. Максимчук, 2015 мереж оперативного керування процесами постачання електроенергії на тягу залізничному транспорту показав величезні можливості в напрямку проведення оптимізації режимів функціонування електричних мереж i надійності електропостачання та відкрив новий етап створення нових підходів комп'ютерної інтелектулізації швидкоплинних процесів електропостачання i розробки, на їх базі, нових перспективних технологій енергозбереження та безпеки руху $[1,2]$. Необхідно відмітити, що на економічність режимів електропостачання на тягу і на надійність функціонування системи електропостачання значно впливає фізичне та моральне старіння силового електричного обладнання тягових мереж залізниць, що находяться в експлуатації. Тому проблема створення енергозберігаючих технологій та покращення рівня безпеки руху потягів при незначних інвестиціях можливо завдяки розробці сучасних методів синтезу розподілених комп'ютерно-інтегрованих мереж комп'ютеризації і інтелектуалізації швидкоплинних технологічних процесів постачання електричної енергії на тягу. Такий підхід стимулював проведення наукових досліджень в області розробки нових принципів організації комп'ютерних засобів і мереж інтелектуалізації режимів оптимального функціонування тягових систем, а також розробки сучасних математичних моделей, методів i комп'ютерно-орієнтованих алгоритмів, адекватних об'єктам керування.

\section{Аналіз останніх досліджень і публікацій}

Сдина енергосистема країни, основними цілями якої є генерація електроенергії, транспорт, розподіл і споживання, представляє собою настільки складну структуру, що навіть при централізованому управлінні 
для оптимальної роботи ії виділяються різні самостійні об'єкти, пов'язані єдиним технологічним ланцюгом, що координується в відповідності 3 режимами споживання. Електрична мережа постачання електроенергії на тягу залізничному транспорту тісно пов'язана 3 єдиною енергосистемою, але має ряд особливостей таких як нерівномірність «рухомих» навантажень, труднощі ідентифікації та захисту від короткого замикання, істотний вплив на лінії передачі інформації. Аналіз проведених досліджень і сучасних публікацій в цьому плані показав, що напрям наукових досліджень, пов'язаний 3 комп'ютеризацією швидкоплинних технологічних процесів постачання електроенергії на тягу та «інтелектуалізацією» енергетики і процедур прийняття оперативних рішень на сьогоднішній день став загальновизнаним у світі [3]. Створення нових моделей комп'ютеризації технологічних енергетичних процесів, методів і апаратно - орієнтованих алгоритмів інтелектуалізації електричних мереж, передбачає проведення наукових досліджень в сфері організації сучасних мережевих і інформаційних технологій для синтезу автоматизованих систем керування процесами електропостачання на тягу. Значну увагу при цьому необхідно виділяти процесам оптимізації витрат i дотримання умов надійності і якості електроенергії, що постачається на тягу. Крім того, необхідно також врахувати розширення ринкових можливостей шляхом надання спектру взаємних послуг між суб'єктами ринку та інфраструктурою електричної мережі залізниць [4]. По оцінкам вітчизняних і зарубіжних вчених, можна зробити висновок, що суттєве збільшення ефективності застосування сучасних комп'ютерних технологій можливе лише шляхом вивчення спільних властивостей математичних моделей, методів, алгоритмів, задач управління, особливостей сучасних i перспективних мережевих технологій, а також архітектурних особливостей систем електропостачання та інформаційно-керуючих комп'ютерних систем.

\section{Відокремлення нерозв'язаних раніше частин загальної проблеми}

Сучасні і перспективні комп'ютерні і мережеві технології для керування технологічними процесами постачання електроенергії на тягу залізничному транспорт відкрили величезні можливості в напрямку проведення оптимізації режимів функціонування та надійності електроспоживання, а також розкрили можливість створення нових технологій енергозбереження і безпеки рух. Необхідно відмітити, що існуючі засоби реєстрації і обробки первинної інформації орієнтовані, в основному, на рішення автономних або сукупності незалежних задач в процесі технологічного чи організаційного керування електропостачанням, що суттєво звужувало можливості забезпечення відповідного рівня якості i унеможливлювало формування керуючих процедур 3 єдиних загальносистемних позицій. При такому підході неможливо досягти високого рівня ефективності й надійності функціонування тягових мереж електропостачання, а також організувати оперативну доставку аварійної і комерційної інформації на всі рівні керування. Рішення в комплексі подібних задач отримує особливе значення при необхідності управління складними територіальнорозподіленими об'єктами, до яких належать мережі електропостачання залізничного транспорту. Сучасні інтегральні технології виготовлення надвеликих інтегральних схем i мікропроцесорних засобів відкрили можливість розробки нових методів синтезу розподілених комп'ютерно-інтегрованих мереж i технологій для проведення моніторингу, комп'ютеризації і інтелектуалізації процесів енергопостачання для оптимізації режимів функціонування тягових електричних мереж. В основу створення корпоративної розподіленої системи безперервного моніторинг та аналізу режимів мереж електропостачання залізниць та силових електричних об'єктів тягових підстанцій використовуються принципи і методи, що базуються на дослідженні спільних властивостей математичних моделей, комп'ютерно - орієнованих методів, алгоритмів функціонування об'єктів, обчислювальних архітектур і мережевих технологій на основі створення єдиного інформаційного простору первинної інформації параметрів режимів тягової мережі кожної залізниці, а також аспектів впливу зовнішнього середовища. Враховуючи специфіку тягових мереж залізниць, значну увагу необхідно приділити розробці математичних моделей i методів ідентифікації аварійних режимів, визначенню місця аварії і захисту системи від короткого замикання. Такий підхід дозволяє також застосовувати принципово нові можливості організації системного захисту тягових мереж шляхом програмного відображення різних ситуацій та ідентифікації несправностей на підставі обробки і аналізу первинної інформації, розширяти набір сервісних функцій, що дуже важливо в умовах ринку електроенергії, а також реалізувати апаратну діагностику і самодіагностику як силових електричних компонентів тягових мереж i всієї системи електропостачання в цілому, так i всіх сегментів розподіленого комп'ютерного середовища $[5,6]$.

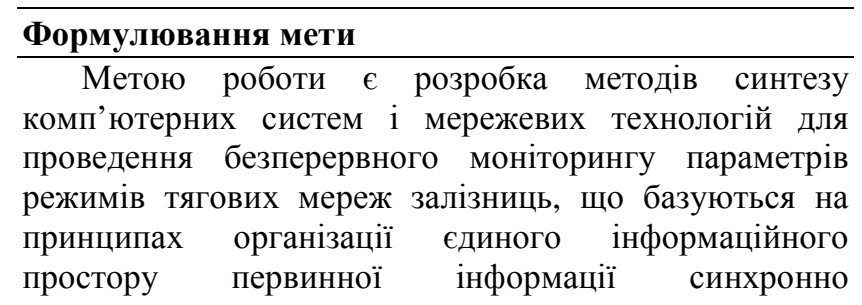


зареєстрованої і сформованої із загальносистемних позицій як основи ідентифікації типів аварійних режимів i визначення місця короткого замикання, оптимізації режимів електропостачання, інтелектуалізації процедур прийняття оперативних рішень, комп'ютеризації швидкоплинних технологічних процесів електроспоживання та формування технологій енергозбереження і безпеки руху залізничного транспорту.

\section{Основний матеріал дослідження

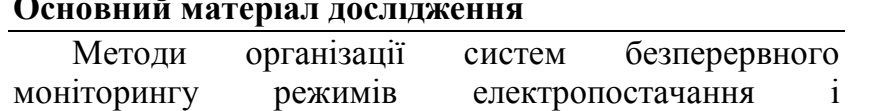 інтелектуалізації процедур електропостачання створюються для проведення контролю обладнання тягових підстанцій, реєстрації аварійних відключень фідерів контактної мережі, ДПР, ліній СЦБ, ліній електропостачання напругою $6-110$ кВ, реєстрації роботи систем релейного захисту, автоматичного визначення параметрів високовольтної ізоляції введень силових трансформаторів, а також автоматичного визначення відстані до місць пошкоджень на фідерах контактної мережі та інших лініях живлення. За рахунок створення єдиного інформаційного простору первинної інформації параметрів режимів тягової мережі кожної залізниці відкривається можливість контролювати за допомогою автоматизованих робочих місць всі тягові підстанції залізниці, що підключені до системи, виконувати в реальному часі діагностування стану технологічного обладнання, простежувати динаміку зміни контрольованих параметрів, проводити оперативний i повний аналіз аварійної ситуації, діагностувати стан електричного обладнання в процесі функціонування. В основу створення корпоративної розподіленої системи безперервного моніторингу та аналізу параметрів режимів мереж електропостачання залізниць та силових електричних об'єктів тягових підстанцій покладені сучасні принципи організації і спільні властивості компонентів системи різної фізичної природи. При цьому первинна інформація, що знімається 3 датчиків мережі електропостачання на тягу, силового електроустаткування тягових підстанцій, систем релейного захисту i других сегментів електричного комплексу залізниць} представляється в аналоговій та дискретній формах.

Первинні дані представляються сукупністю аналогових сигналів таких як струми I, напруги U, частота живлення $\mathrm{f}$, проміжки часу $\tau_{\mathbf{i}}$, вологість, температура, Р-тиск газу високовольтних вимикачів, значення концентрації газу, а також набором дискретних сигналів, що поступають від системи захисту. Первинна інформація формується у вигляді єдиного інформаційного простору з загальносистемних позицій. Такий підхід дозволяє одноманітно обробляти iii паралельно в компонентах розподіленої архітектури обчислювального середовища, що забезпечує високу точність обробки інформації і достовірність та якість представлення на всіх рівнях керування. При цьому, сформована таким чином первинна інформація $є$ також загальною для відтворення доаварійних, аварійних i після аварійних режимів синхронно 3 роботою в реальному часі систем захисту, для проведення спектрального аналізу аномального режиму i визначення інших показників функціонування тягової електричної мережі. Подібна організація інформаційних ресурсів, що відображають режими електропостачання, відкриває можливість ідентифікувати аварії, проводити в реальному часі оперативний i повний аналіз аномальних режимів, реалізувати інтелектуальну обробку первинних даних i, на їх базі, формувати сучасні технології енергозбереження в процесі постачання електроенергії територіально розподіленими електричними мережами та, завдяки цьому, суттєво збільшити рівень безпеки руху залізничного транспорту. Такий підхід дозволяє також застосовувати принципово нові можливості організації системного захисту тягових мереж шляхом програмного відображення різних ситуацій та ідентифікації несправностей на підставі ситуаційного моделювання, розширяти набір сервісних функцій, що дуже важливо в умовах ринку електроенергії, а також реалізувати апаратну діагностику і самодіагностику як силових електричних компонентів тягових мереж i всієї системи електропостачання в цілому, так і всіх сегментів розподіленого комп'ютерного середовища. Розглянемо організацію архітектури розподіленого комп'ютерного середовища для проведення безперервного моніторингу і оцінки технічного стану потужних електричних об'єктів і мереж залізниць, інтелектуального обліку електроенергії, включаючи ряд сервісних функцій взаємовідносин 3 ринком електроенергії. Така інформаційна обчислювальна система орієнтована на вирішення проблеми диспетчерського i технологічного управління процесами електропостачанням в масштабі галузі, а також сукупності глобальних задач економічного й експлуатаційного характеру, зокрема питання оптової купівлі, споживання i продажу електроенергії не тяговим i районним споживачам. Базовим загальносистемним принципом організації такої розподіленої комп'ютерної систем контролю, дослідження i управління режимами електричних об'єктів і мереж залізниць є принцип єдиного інформаційного синхронного простору формування первинної інформації параметрів режимів тягових електричних систем, що відповідає умовам синхронності і єдності вимірювання первинних джерел інформації та дозволяє організувати оперативне функціонування перспективних і ретроспективних баз даних, уніфікацію документообігу, а також організацію інтерфейсу користування на підставі спеціалізації автоматизованих робочих місць. 
Архітектура розподіленого комп'ютерного середовища корпоративної інтегрованої системи для моніторингу режимів, діагностування стану, оптимізації електроспоживання та підвищення надійності перевезень й ефективності управління електричними мережами залізниць подана на рис. 1. Вона представлена у вигляді трьох рівнів. Перший рівень архітектури єдиного комп'ютерного середовища представлений у вигляді спеціалізованої локальної комп'ютерної мережі, за основу логічної структури якої може бути прийнятна люба фізична топологія. В локальній мережі для управління технологічними процесами електропостачання на рівні тягових підстанцій в якості мережевих вузлів використовується сервер,на який положено сукупність задач управління роботою компонентів i сегментів комп'ютерної мережі, а також формування первинної інформації у вигляді єдиного інтегрованого середовища i ряд процедур ведення бази аварійних і комерційних даних. Крім того, в комп'ютерній локальній мережі тягової підстанції в якості мережевих вузлів використовуються мікропроцесорна система безперервного моніторингу й ідентифікації режимів електричного обладнання і мереж електропостачання тягових підстанцій, системи визначення запасу ресурсу високовольтних вимикачів, мікропроцесорна структура безперервного моніторингу діелектричних параметрів трансформаторів, системи інтелектуального обліку електроенергї по комерційним тарифам, диференційованим за зонами доби, системи збору інформації від мікропроцесорних пристроїв релейного захисту та ін. Для організації роботи комп'ютерної мережі тягової підстанції в системі єдиного комп'ютерного середовища i, відповідно, реалізації оперативного обміну інформацією між сегментами корпоративної мережі використовується сервер опитування i шлюз Internet, a для оперативного керування використовується АРМ диспетчера. При необхідності, в залежності від типу тягової підстанції, може бути також АРМ технолога, АРМ організації звітних документів i інші типи автоматизованих робочих місць. В процесі комп'ютеризації швидкоплинних технологічних процесів розглянутий комплекс задач на рівні тягових підстанцій взагалі і вирішується автоматично, однак в процесі моніторингу, інтелектуального обліку електроенергії і других процедур управління може привести до накопичення великих об'ємів інформації, то сервер має бути захищений комплексом апаратно - програмних засобів від несанкціонованого доступу. В той же час, для своєчасної передачі інформації на більш високі рівні керування електропостачанням залізниць, сервер локальної мережі тягової підстанції має працювати через маршрутизатор віддаленого офісу, який з'єднує локальну мережу 3 мережею дистанції електропостачання, залізниці або Укрзалізниці.
Продуктивність таких маршрутизаторів дозволяє реалізувати декілька десятків тисяч протоколів за секунду. В деяких випадках використовуються методи розвантаження локальних мереж від трафіку передачі інформації, наприклад, шляхом сегментації. Такий підхід дозволяє об'єднання однорідних термінальних вузлів у комп'ютерній локальній мережі нижнього рівня 3 топологією «спільна шина». В умовах ринку електроенергії появляється необхідність передавати великі об'єми інформації за короткий проміжок часу, а також для своєчасної локалізації аварій необхідно формування і передача аварійних даних миттєво, в таких випадках для локальних мереж канали передачі даних вибираються за умовою необхідної пропускної спроможності, вартості, надійності і зручності в експлуатації. Для локальних мереж тягових підстанцій, що виконують реєстрацію і обробку великих об'ємів інформації, доцільно використовувати високошвидкісні оптоволоконні лініі, а для вузлів або сегментів системи, які не потребують високої швидкості передачі даних, пропонується виту пару.. В процесі функціонування комп'ютерної локальної мережі тягової підстанції появляється необхідність організації, в реальному часі, контролю, достовірності, цілісності, і конфіденційності в процесі передачі інформації. Топологія локальної мережі тягової підстанції, в процесі роботи, може також мінятися у залежності від класу задач, що необхідно розв'язувати в той чи інший проміжок часу, а також від стану системи електропостачання, комп'ютерної мережі та об'єму трафіку. Широкі можливості в плані організації динамічної структури комп'ютерної локальної мережі без зміни фізичної топології, що визиває суттєві трудності, можливо завдяки використанню магістральних маршрутизаторів або програмних комутаторів. Відмітимо, що на сервері локальної мережі виконується також організація первинної інформації з єдиних загальносистемних позицій. 

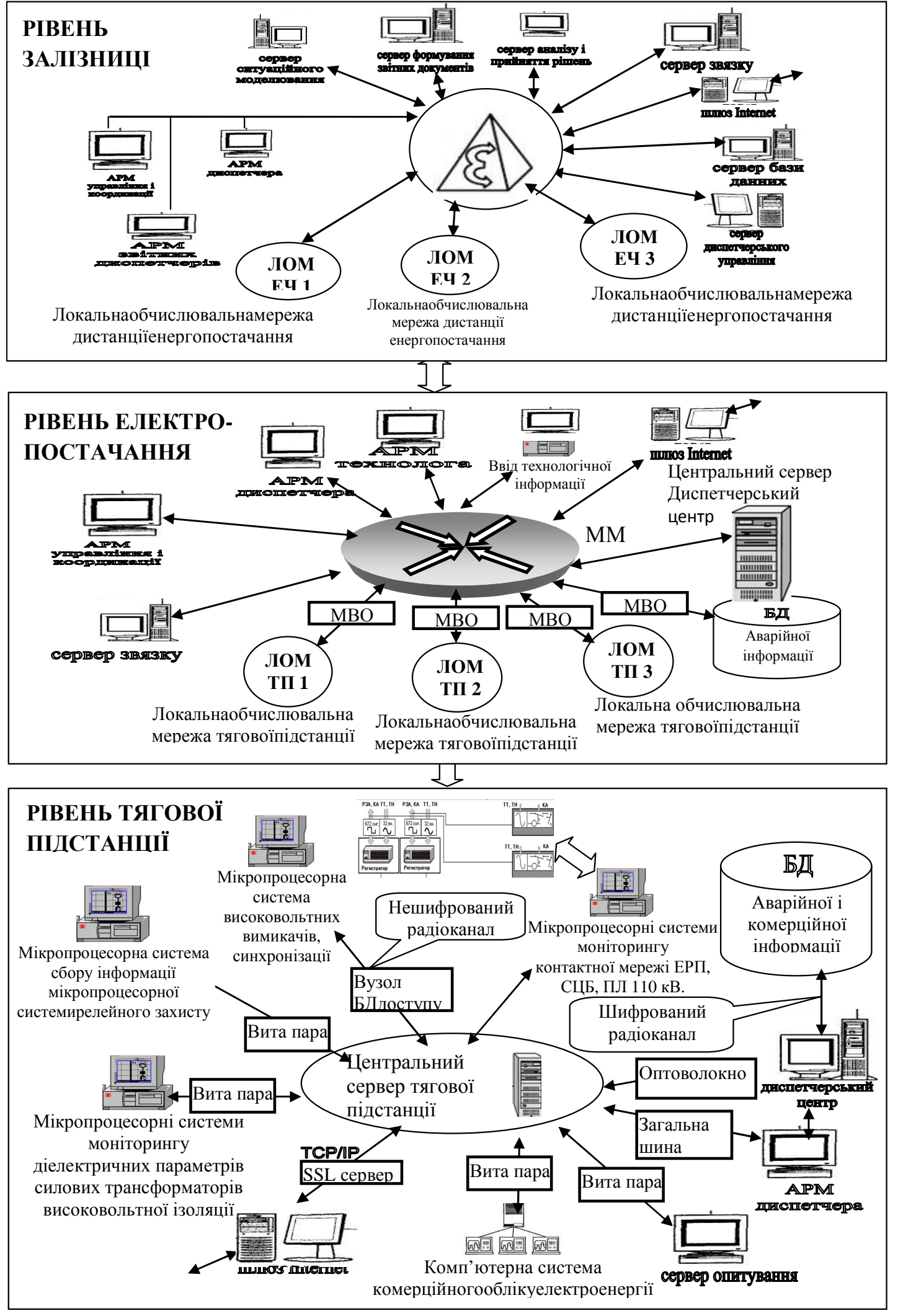

Рис.1. Корпоративна система управління електропостачанням 
Подібна організація первинних даних відкриває можливість формування i передачу на всі рівні керування експрес-аварійної інформації, а для аналізу і ідентифікації аномальних режимів створювати $\mathrm{i}$, відповідно, передавати по запиту, файли повного аварійного режиму та комерційних даних. Рівень організації комп'ютерної локальної мережі тягових підстанцій є домінуючим з точки зору формування та збереження первинної інформації, яка відображає режими функціонування систем електропостачання залізниць. При цьому первинна інформація архівується i, згідно 3 нормативними документами, зберігається в необробленому виді необхідний термін. Дослідження і комп'ютеризація процесів електропостачання на тягу, достатньо ефективно може бути реалізовано на наступному рівні ієрархії розподіленого комп'ютерного середовища корпоративної інтегрованої системи, що по суті представляє собою рівень дистанції електропостачання ЕЧ залізниці [3-5]. На кожній залізниці дистанцій ЕЧ може бути від п'яти до восьми, а кожна дистанція ЕЧ включає до восьми різних типів тягових підстанцій. Відповідно другий рівень розподіленого комп'ютерного середовища представлений у вигляді регіональної комп'ютерної мережі, вузлами якої $\epsilon$ спеціалізовані локальні комп'ютерні мережі тягових підстанцій. Зв'язок між локальними і регіональною мережею реалізується за допомогою магістрального маршрутизатора. Регіональна мережа включає центральний сервер на базі якого сформовано диспетчерський центр оперативного керування технологічними процесами електроспоживання відповідного сегмента системи електропостачання, а також на нього положено ряд функцій координації i обміну інформацією 3 комп'ютерними мережами верхнього та нижнього рівня ієрархії єдиного комп'ютерного середовища. Топологія логічної структура регіональної мережі організована у вигляді «зірка», а в якості сегментів іiі виступають, відповідно, локальні мережі тягових підстанцій. Формування кожного сегмента регіональної мережі залежить як від величини електричної мережі дистанції електропостачання, так i від кількості її автономних сегментів.

Центральний сервер виконує також ряд функцій, пов'язаних 3 формуванням єдиного інформаційного простору частково первинної і вторинної інформації, яка отримується із всіх локальних мереж тягових підстанцій, що включені в регіональну комп'ютерну мережу дистанції електропостачання, а також, реалізується ведення розподіленої бази аварійної i комерційної інформації. На цьому рівні виконується також обробка інформації, пов'язаної 3 аналізом розвитку аварійних ситуацій, оцінки функціонування пристроїв релейного захисту та автоматики, визначення місць пошкоджень під час коротких замикань на лініях електропередачі, визначення залишкового ресурсу силових вимикачів та побудови добової відомості. Крім того, на цьому рівні виконується архівація інформації, реалізується ведення баз даних, а також формування звітних документів і формування блоку інформації, яка передається на наступний рівень диспетчерського управління залізницею. У випадку, якщо на першому рівні комп'ютерного середовища не достатньо обчислювальної потужності, то на рівні регіональної комп'ютерної мережі $\epsilon$ можливість обробки синусоїдальних сигналів електричних параметрів струму і напруги, а саме проведення фазового та гармонічного аналізу, визначення симетричних складових у трифазних мережах змінної напруги, виведення інформації у вигляді текстових повідомлень, графіків, гістограм. Результати обробки інформації в регіональній комп'ютерній мережі формується у файли відповідно 3 державною та корпоративною нормативною базою для відповідних інженерних, економічних та адміністративних служб Укрзалізниці, обленерго, незалежних постачальників енергоринку і доступні локальним мережам тягових підстанцій, i передаються на наступний рівень диспетчерського центру управління електричними мережами залізниці. Верхній рівень розподіленого комп'ютерного середовища корпоративної інтегрованої системи дослідження i керування електропостачанням залізниць представлений у вигляді корпоративної обчислювальної мережі (рис.1). Вона представляе собою набір регіональних комп'ютерних мереж i сегментів, об'єднаних між собою слабо пов'язаними високошвидкісними лінями зв'язку, що забезпечують обмін інформацією $[4,5]$. Особливою відзнакою корпоративної мережі є те, що в ній обов'язково необхідно визначати і враховувати умовний баланс об'єму трафіку та пропускної спроможності каналів зв'язку. Цей момент обумовлений можливими чергами в процесі доставки пакетів, кадрів і повідомлень, а також можливими затримками, втратами та повторними передачами. Організація повторних передач додатково завантажує мережу, а в час пік перевантаження може розвиватися лавиноподібно. Тому, виходячи із допустимого ризику перевантаження i таких факторів, як статистичні характеристики трафіку та можливий додатковий об'єм інформації, визначається коефіцієнт використання мережі як відношення пропускної спроможності до максимальної швидкості передачі даних. Неврахування ряду подібних факторів в процесі керування мережею, трафіком, а також незадовільна маршрутизація можуть привести до критичного перевантаження та зупинки мережі, що, в свою чергу,унеможливлює управління в реальному часі швидкоплинними технологічними процесами постачання електроенергії на тягу та до значного зниження рівня безпеки руху потягів. На центральний 
сервер корпоративної мережі положено функції організації функціонування системи та обміну інформацією, а також задачі інтелектуалізації формування процедур прийняття оперативних i стратегічних рішень на всіх рівнях залізниці. Зв'язок центрального серверу реалізується за допомогою високонадійних магістральних маршрутизаторів, а в деяких випадках програмних комутаторів. Захист сервера може бути реалізований шляхом формування мережевого параметру, який включає спеціалізовані проксі-сервер для фільтрації трафіку та управління доступу до ресурсів. На третьому рівні проводиться моделювання режимів та прогноз запасу надійності функціонування електричної системи електропостачання окремої залізниці для поліпшення безпеки руху залізничного транспорту. Також реалізується ситуаційне моделювання режимів постачання електроенергії за тарифами, диференційованими по зонах доби, що дозволяє мінімізувати комерційну вартість електроенергії, що споживається на тягу,і формувати сучасні технології енергозбереження. Беручи до уваги той фактор, що в процесі моніторингу i керування електричним господарством окремої залізниці, відповідно, на рівні тягових підстанцій і дистанцій електропостачання,в базах даних локальних і регіональних обчислювальних мереж формуються великі об'єми інформації, що затрудняє оперативний аналіз. Тому головною задачею корпоративної мережі $\epsilon$ інтелектуальна обробка інформації та представлення ii у вигляді готових альтернативних рішень диспетчерському персоналу.

\footnotetext{
Висновки

1. Аналіз комплексної проблеми управління режимами енергозбереження систем електропостачання залізниць показав, що рішення пї можливо шляхом пошуку нових сучасних принципів i методів синтезу розподілених комп'ютерних систем і мережевих технологій адекватних топології мереж постачання електроенергії на тягу залізниць, що дозволяють реалізувати, в реальному часі, безперервний моніторинг параметрів режимів систем електропостачання, i на основі отриманих даних, ідентифікацію стану, інтелектуалізації процедур управління електроспоживання.

2. На основі дослідження спільних властивостей математичних моделей, методів, алгоритмів, задач управління електричними мережами та особливостей сучасних комп'ютерних засобів, запропоновані методи синтезу розподілених комп'ютерних мереж i інформаційних технологій проведення ковзкого безперервного моніторингу швидкоплинних технологічних процесів постачання електроенергії на тягу. Даний підхід дозволить реалізувати оптимізацію електроспоживання, мінімізувати втрати, сформувати
}

енергозберігаючі технології, що дозволить збільшити надійності функціонування системи електропостачання, і як наслідок, покращити рівень безпеки руху залізничного транспорту.

3. Запропонована архітектура розподіленого багаторівневого комп'ютерного середовища орієнтована на вирішення проблеми диспетчерського і технологічного управління процесами електропостачанням в масштабі галузі, а також рішення сукупності глобальних задач економічного й експлуатаційного характеру, зокрема питання оптової купівлі, споживання i продажу електроенергії не тяговим і районним споживачам.

\section{Література}

1. Стогний Б.С. Методы организации компьютерных систем коммерческого управления электрическими объектами. //Стогний Б.С., Сопель М.Ф., Стасюк А.И., Стасюк И.А Зб. наукових праць. Моделювання та інформаційні технології./ Випуск 15, НАН України. Інститут проблем моделювання в енергетиці ім. Г.Є. Пухова. Київ - 2002.- С.3-15.

2. Стогній Б.С. Еволюція інтелектуальних електричних мереж та їхні перспективи н в Україні // Стогній Б.С., Кириленко О.В., Праховник А.В., Денисюк С.П. ; Технічна електродинаміка 2012, №5 - С. 52-66.

3. Стасюк O.I. Методи організації інтелектуальних електричних мереж залізниць на основі концепції SMART Grid// Гончарова Л.Л., Максимчук В.Ф. Інформаційно-керуючі системи на залізничному транспорті, Харків - 2014, № 2 -С.29 -37

4. Стасюк O.I. Методи організації комп'ютерної мережі моніторингу параметрів режимів систем електропостачання // Стасюк O.I., Гончарова Л.Л., Максимчук В.Ф., Інформаційно-керуючі системи на залізничному транспорті, № 2, 2012 -С.35 - 40

5. Стасюк О.І. Підвищення надійності моніторингу допустимості завантажень контрольованих перетинів енергосистем // Стасюк O.I., Буткевич О.Ф., Левконюк А.В. Технічна електродинаміка, Київ - 2014, №2 - С.56-67.

6. Стасюк O.I. Методи комп'ютерної інтелектуалізації режимів функціонування тягових мереж залізниць// Стасюк О.І., Гончарова Л.Л., Максимчук В.Ф., Голуб Г.М.,Інформаційнокеруючі системи на залізничному транспорті, Харків - 2013, № 5 -С.29-36. 
Стасюк А.И., Гончарова Л.Л., Максимчук В.Ф. Методы синтеза распределенных компьютерноинтегрированых сетей, мониторинга и оптимизации режимов электроснабжения и энергосбережения железных дорог. Рассмотрены вопросы синтеза распределенных компьютерных сетей для проведения скользящего беспрерывного мониторинга быстропротекающих технологических процессов снабжения электроэнергии на тягу железнодорожному транспорту, организации единого пространства первичной информации для проведения оптимизации электропотребления, минимизации потерь, организации энергосберегающих технологий и улучшения уровня безопасности движения поездов.

Ключевые слова: компьютерные сети, мониторинг, первичная информация, оптимизация, процесс.

Stasiuk A.I, Goncharova L.L, Maksymchuk V.F. Methods for the synthesis of distributed computer integrated networks, monitoring and optimization of electricity and energy saving of railways. The synthesis problems of distributed computer networks for sliding uninterrupted monitoring of high-rate technological processes of electricity supply for railway transport traction have been considered. Also the problems of the organization of a unified space of primary information for power consumption optimization, losses minimization and for the organization of energy saving technologies and the improvement of train movement safety level have been considered.

Key words: computer networks, monitoring, primary information, optimization, process.

Рецензент д.т.н., професор Тимченко Л.І. (ДЕТУТ)

Поступила 13.11.20142. 